\title{
ENVIRONMENT RESILENT RICE STUBBLE MANAGEMENT TECHNIQUE FOR WHEAT SOWING IN ZERO TILLAGE HAPPY SEEDER
}

\author{
Memoona Shehzadi ${ }^{1}$, Abdul Khaliq*2, Muhammad Shafqat ${ }^{1}$, Rashad-ul-Sher ${ }^{1}$, Adeel Ahmad ${ }^{3}$, \\ Muhammad Younus², Mubashra Yasin² \\ 1. Agronomic Research Station Farooqabad \\ 2. Sugarcane Research Institute Faisalabad \\ 3. Department of Agronomy, University of Agriculture Faisalabad \\ Corresponding author email: khaliq1775@gmail.com
}

\begin{abstract}
:
Rice wheat cropping system prevailed in more than fifty percent areas of rice belt of central and upper Punjab. In this area yield of wheat is curtailed every year due to late harvesting of rice crop. In addition to this, lack of machinery for direct sowing of wheat into combine harvested rice is a major limitation for timely wheat sowing due to presence of heavy straw load dropped by the combine harvester. A field experiment was planned and executed during two consecutive years 2017-18 and 2018-19 at Agronomic Research Station Farooqabad to evaluate the various stubble management techniques for the sowing of wheat in a rice-wheat cropping system. The Experiment consist of four treatments Happy seeder (Zero tillage), conventional sowing without burning of rice stubble, Rotavator two times, and Conventional sowing with the burning of rice stubble. The trail was arranged as Randomize Complete Block Design with four replications having a net plot size of $8 \mathrm{~m}$ x $20 \mathrm{~m}$. The Treatments have significant effects on Plant height, Number of productive tillers, 1000- grain weight and grain yield. Maximum plant height $(94.74$ and $94.25 \mathrm{~cm})$, numbers of productive tillers $/ \mathrm{m}^{2}$ (324.00 and 322.25), 1000-grain weight (36.35 and $36.20 \mathrm{~g}$ ), grain yield ( 3780 and $3613 \mathrm{~kg} / \mathrm{ha}$ ), and benefit-cost ratio (2.54 and 2.43) were recorded from the treatment happy seeder (Zero tillage) during both years respectively. It is concluded that sowing of wheat with a happy seeder (Zero tillage) is appropriate technique in the rice-wheat cropping system by protecting the environment and soil health from burning of rice stubbles.
\end{abstract}

Keywords: Stubble management, Tillage system, Rice wheat cropping system, happy seeder

\section{INTRODUCTION}

Exhaustive cultivation under wheat rice cropping system from many years resulted in scarce of essential nutrients, poor organic matter and soil health, leading to unsustainability of cropping systems $(1,2)$. Agricultural lands are one of important Natural resources that are limiting day by day Pakistan. In this scenario, it is the need of time to improve cropping systems to increase vertically yield of crops and food grains to meet the feed the increasing population (3).

The rice-wheat cropping system is prevailing in more than fifty percent area of central and upper Punjab. The productivity of this system is declining day by day due to poor soil health and delay in wheat planting. There are many reasons behind this poor crop yields in this system which 
includes poor return of nutrients to the soil due to continuous cropping, declining organic matter, no crop rotation, illiteracy in farmer communities, lack of improved farm implements and model farms and poor financial conditions of farmers etc (4). The introduction of farm machinery for mechanically sowing of crops is the basis in sustainability of the rice-wheat cropping system. Innovative interventions are vital to optimize the rice-wheat production system in this region on sustainable basis (5)

. The development of highly fertilizer and irrigation responsive rice and wheat varieties produce massive quantities of rice and wheat grains and also residues. In past both wheat and rice straw were removed from the fields by the village people and used as cattle feed, fuel and livestock bedding. Now rice and wheat harvesting is mechanized and demand for straw has been dropped. Combines harvested rice left the crop residues in the field which were burnt before soil preparation for wheat sowing $(6,7)$.

In the rice-wheat zone, Basmati rice are preferred to grow due to its aroma, higher price, better cooking quality, and taste. Basmati rice, being a long duration and late-maturing variety, ultimately causes a delay in sowing of wheat. About $40 \%$ nitrogen, $30-35 \%$ phosphorus, $80-85 \%$ potassium, and 40-50\% sulfur (S) present in vegetative parts of a plant which rice acquired during its growth period $(8,9)$

All nutrients which are present in rice straw are lost due to burning (10). This results in severe air pollution and loss of nutrients and organic matter (11). Burning is helpful only because it helps in clearing soil surface quickly and killing soil-borne insects and pathogens but at the same time, it plays a considerable part in increasing air pollution and killing off beneficial soil insects and microorganisms and a huge amount of nutrient loss (12).

To cope these issues, the concept of 'zero tillage' i.e. drill seeding into uncultivated soil, for wheat began in the late 2000 in rice track of central and upper Punjab. This technique is smart to farmers being cost savings got from reduced use of fuel and labour and with better yield benefits. Earlier sowing of wheat compete against its major weed (Phalaris minor) potentially. Accordingly, the area of zero tillage wheat in Rice belt has extended exponentially (13).

However, successful zero tillage after combine-harvested rice is possible only with burning the rice straw and stubbles in rice furrows which may result in uneven sowing due frequent 
chopping drill and lifting of the drill to clear blockages $(11,13)$. Then, most rice stubbles are burnt in the mechanized rice--wheat systems of Pakistan, as it allows for quick turnaround between crops being rapid and cheap way. As regarding with loss of organic matter, rice stubble burning causes widespread air pollution in areas where rice-wheat systems prevailed. A novel approach is the use of Happy Seeder, which combines the stubble mulching and seed drilling functions in the one operation.

\section{MATERIAL AND METHODS}

A field trial was conducted at Agronomic Research Station Farooqabad, Sheikhupura, Pakistan. A Randomized Complete Block Design having four replications was used. The net plot size was $8 \mathrm{~m} \times 20 \mathrm{~m}$ with variety of wheat Faisalabad-2008.

Crop was sown during Rabi 2017 and 2018 to evaluate the various stubble management techniques for sowing of wheat in rice-wheat cropping system. Crop was sown with seed rate of $125 \mathrm{~kg} \mathrm{ha}^{-1}$. A recommended dose of fertilizer added with the ratio of 120:60:60 $\mathrm{kg} \mathrm{ha}^{-1}$ for NPK respectively. The experiment comprised of following four treatments:

T1: Happy seeder (Zero tillage)

T2: Conventional sowing without burning of rice stubble

T3: Rotavator two times

T4: Conventional sowing with Burning of rice stubble

Irrigation was applied at critical growth stages of crop; first irrigation was applied at crown root stage, second at booting, third at heading and fourth at grain filling stage by keeping in mind the rainfall and temperature during the experiment. The previous rice crop was harvested with the help of combine harvester. The soil sampling was done before sowing of experiment.

\section{Fig. 1}
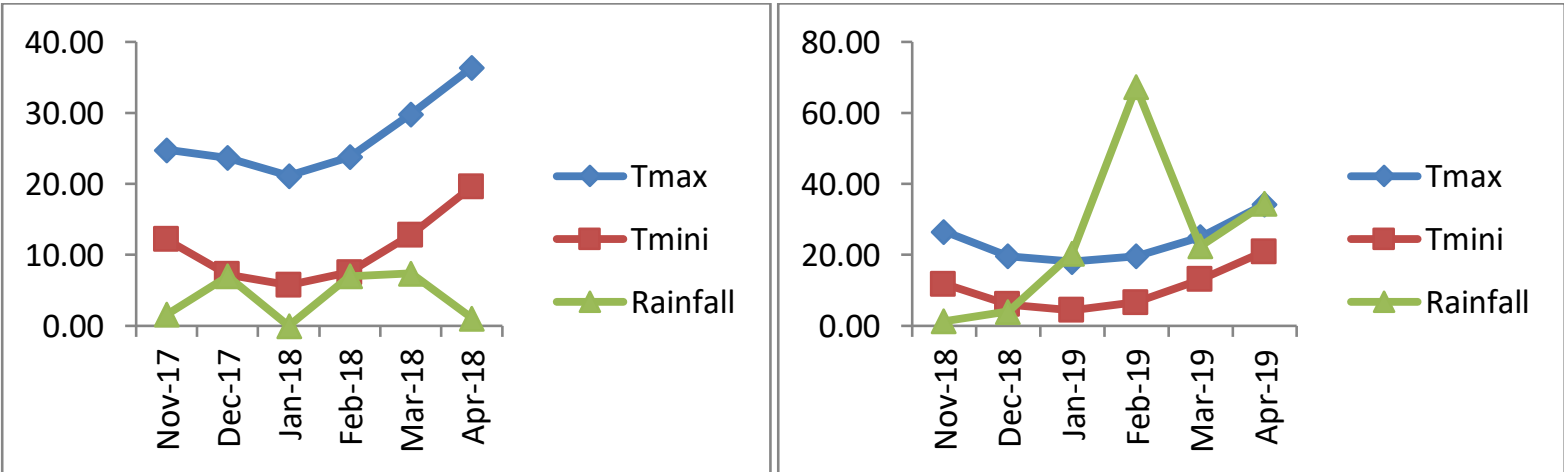


\section{Metrological data 2017-18 and 2018-19 maximum temperature $\left({ }^{\circ} \mathrm{C}\right)$, minimum temperature $\left({ }^{0} \mathrm{C}\right)$ and Rainfall ( $\left.\mathrm{mm}\right)$}

\section{Site Descriptions:}

The soil of the experimental fields at agronomic research station Farooqabad is clay loam. The soils were non saline and non-sodic with $\mathrm{pH}$ ranging from 7.5 to 7.8 and organic matter varies from 0.74 to $0.77 \%$. The climate of the region is subtropical. Average annual rainfall is $488 \mathrm{~mm}$. The mean daily minimum and maximum temperatures during the rice season 2017 (July-October) was $24.37{ }^{\circ} \mathrm{C}$ and $35.67{ }^{\circ} \mathrm{C}$, while in 2018 (July-October) was $23.80^{\circ} \mathrm{C}$ and $34.68^{\circ} \mathrm{C}$ respectively, compared with $10.86^{\circ} \mathrm{C}$ and $26.60^{\circ} \mathrm{C}$ during $2017-18,10.49^{\circ} \mathrm{C}$ and $23.88^{\circ} \mathrm{C}$, during the wheat season 2018-19.

\section{Data Collection:}

Data regarding plant height, number of productive tillers $\mathrm{m}^{-2}$ and 1000 -grain weight $(\mathrm{g})$ were recorded at maturity by using standard procedures. Grain yield $\left(\mathrm{kg} \mathrm{ha}^{-1}\right)$ were recorded by randomly taking three samples of $1 \mathrm{~m}^{2}$ from each plot and then converted this quantity in $\mathrm{kg} \mathrm{ha}^{-1}$ and analyzed statistically by employing statistics 8.1 and all means were compared by using Least significant Difference test (14).

\section{RESULTS AND DISCUSSION:}

In this experiment, all the results were found significant in all treatment. Data regarding plant height was recorded at maturity and presented in table.2. Statistical analysis of the data showed the significant difference among treatment means. The maximum plant height was recorded in the plots where wheat was sown with the help of Happy Seeder in zero tillage (94.74 $\mathrm{cm}, 94.25 \mathrm{~cm})$ while minimum plant height $(88 \mathrm{~cm}, 86.50 \mathrm{~cm})$ was recorded from the plots where wheat was sown conventionally after burning of rice stubbles during both years respectively. The reason behind more plant height in zero tillage with happy seeder is that weeds minimized in this treatment due to dominance of wheat crop and favorable environmental conditions. These results are line with the findings of $(11,12)$. 
Table. 1: Soil Analysis Report

\begin{tabular}{|l|c|c|}
\hline Soil Analysis & $\mathbf{2 0 1 7 - 1 8}$ & $\mathbf{2 0 1 8 - 1 9}$ \\
\hline Soil type & Clay Loam & Clay Loam \\
\hline $\mathrm{pH}$ & 7.8 & 7.5 \\
\hline Organic matter (\%) & 0.74 & 0.77 \\
\hline Phosphorus (ppm) & 8.5 & 8.7 \\
\hline Potassium (ppm) & 110 & 130 \\
\hline $\mathrm{N}(\%)$ & 0.035 & 0.045 \\
\hline
\end{tabular}

The productive tiller $\mathrm{m}^{-2}$ play a vital role in grain yields of the wheat. The data regarding No. of productive tillers $\mathrm{m}^{-2}$ was recorded at maturity and presented in table.2. Data revealed that the maximum number of tillers $\mathrm{m}^{-2}(324.00,322.25)$ were produced by the plots where wheat was sown by Happy Seeder in zero tillage and the minimum number of tillers $\mathrm{m}^{-2}$ (262.00, 259.00) were recorded where wheat was sown by conventional method after the burning of rice stubbles during both years respectively. These results are in consistent with the findings of $(6,9)$

Table. 2: Effect of various rice stubble management techniques on plant height (cm) and number of productive tillersm ${ }^{-2}$ of wheat crop

\begin{tabular}{|c|c|c|c|c|}
\hline & \multicolumn{2}{|c|}{$2017-18$} & \multicolumn{2}{|c|}{$2018-19$} \\
\hline Treatments & $\begin{array}{l}\text { Plant height } \\
(\mathrm{cm})\end{array}$ & $\begin{array}{l}\text { No. of productive } \\
\text { tillers } / \mathrm{m}^{2}\end{array}$ & $\begin{array}{l}\text { Plant height } \\
(\mathrm{cm})\end{array}$ & $\begin{array}{l}\text { No. of } \\
\text { productive } \\
\text { tillers } / \mathrm{m}^{2}\end{array}$ \\
\hline Happy seeder (Zero tillage) & $94.74 \mathrm{~A}$ & $324.00 \mathrm{~A}$ & $94.25 \mathrm{~A}$ & $322.25 \mathrm{~A}$ \\
\hline $\begin{array}{l}\text { Conventional sowing without burning of rice } \\
\text { stubble }\end{array}$ & $90.16 \mathrm{~B}$ & $271.75 \mathrm{~B}$ & $87.58 \quad \mathrm{~B}$ & $266.75 \mathrm{~B}$ \\
\hline Rotavator two times & $90.49 \mathrm{~B}$ & $276.00 \mathrm{~B}$ & $90.33 \mathrm{AB}$ & $272.75 \mathrm{~B}$ \\
\hline $\begin{array}{l}\text { Conventional sowing with Burning of rice } \\
\text { stubble }\end{array}$ & $88.00 \mathrm{~B}$ & $262.00 \mathrm{~B}$ & $86.50 \mathrm{~B}$ & 259.00 \\
\hline LSD Value & 4.15 & 18.66 & 4.040 & 16.75 \\
\hline
\end{tabular}

Means sharing the same letter do not differ significantly at $\mathrm{P} \leq .05$.

Thousand grain weight has a key role in grain yield per hectare. The date presented in the table.3 showed the significant effect of different treatments on 1000-grain weight. Maximum 
1000-grain weight was produced by the plots where wheat was sown by Happy Seeder in zero tillage (36.35 g, $36.20 \mathrm{~g}$ ) while minimum 1000-grain weight (33.85 g, $33.68 \mathrm{~g})$ was recorded from the plots where wheat was sown conventionally after the burning of rice stubbles during both years respectively. These results are line with the findings of (10.12) that grain size increase in use of happy seeder resulting in better thousand grain weight in timely sowing.

Table. 3: Effect of various rice stubble management techniques on thousand grain weight (g) and grain yield (kg/ha) of wheat crop

\begin{tabular}{|c|c|c|c|c|}
\hline & \multicolumn{2}{|c|}{ 2017-18 } & \multicolumn{2}{|c|}{ 2018-19 } \\
\hline Treatments & $\begin{array}{c}\text { 1000-grain wt. } \\
\text { (g) }\end{array}$ & $\begin{array}{c}\text { Grain yield } \\
\text { (kg/ha) }\end{array}$ & $\begin{array}{c}\text { 1000-grain } \\
\text { wt. (g) }\end{array}$ & $\begin{array}{c}\text { Grain yield } \\
\text { (kg/ha) }\end{array}$ \\
\hline Happy seeder (Zero tillage) & $36.35 \mathrm{~A}$ & $3780 \mathrm{~A}$ & $36.20 \mathrm{~A}$ & $3613 \mathrm{~A}$ \\
\hline Conventional sowing without burning of rice stubble & $34.40 \mathrm{~B}$ & $3180 \mathrm{~B}$ & $34.39 \mathrm{~B}$ & $3075 \mathrm{~B}$ \\
\hline Rotavator two times & $34.59 \mathrm{~B}$ & 3217 B & $34.50 \mathrm{~B}$ & 3125 B \\
\hline Conventional sowing with Burning of rice stubble & $33.85 \mathrm{~B}$ & 3049 B & 33.68 & $2800 \mathrm{~B}$ \\
\hline LSD Value & 1.0056 & 325.38 & 0.5660 & 405.69 \\
\hline
\end{tabular}

The data regarding the grain yield was recorded at the harvesting and presented in table.3. The data showed that the different rice stubbles management practices have a statistically significant effect on the grain yield. The data showed that the maximum grain yield $\left(3780 \mathrm{~kg} \mathrm{ha}^{-1}\right.$ and $3613 \mathrm{~kg} \mathrm{ha}^{-1}$ ) in 2017-18 and 2018-19 were produced respectively from the plot where wheat was sown with the help of Happy Seeder without burning of rice stubbles and without ploughing of land. While the minimum grain yield (3049 $\mathrm{kgha}^{-1}$ and $2800 \mathrm{kgha}^{-1}$ ) was produced from the plots where wheat was sown by using conventional method after the burning of rice stubbles during both years respectively. These results are line with the findings of $(3,4,7)$ who sated that increase in thousand grain weight, plant height and number of tillers may lead to higher grain yield.

\section{Benefit Cost Ratio}

Benefit cost ratio (BCR) is also imperative to farmers because they interested in the increasing net returns with given increase in the total cost of production. In table. 4 comparative economics was 
calculated of different rice stubble management practices in wheat. In treatment where sowing of wheat was done with happy seeder, the expenses during 2017-18 and 2018-19 was incurred of Rs. 47770/- and Rs. 53400/- respectively. Similarly Income and benefit cost ratio during these years was obtained Income Rs. 122850/- and 126455/- and BCR 2.57 and 2.37 respectively. BCR value in happy seeder treatment is high because it curtailed the expenses of agricultural operations to be incurred on soil preparation. The timely sowing of wheat with happy seeder in rice residues produced highest grain yield fetching highest net return.

Table.4: BENEFIT COST RATIO

\begin{tabular}{|c|c|c|c|c|c|c|c|c|c|}
\hline \multirow[b]{2}{*}{ Treatments } & \multicolumn{2}{|c|}{ Yield (Kg/ha) } & \multirow{2}{*}{$\begin{array}{l}\text { Expenses } \\
(2017-18)\end{array}$} & \multirow{2}{*}{$\begin{array}{l}\text { Expenses } \\
(2018-19)\end{array}$} & \multirow{2}{*}{$\begin{array}{l}\text { Income } \\
(2017-18)\end{array}$} & \multirow{2}{*}{$\begin{array}{l}\text { Income } \\
(2018-19)\end{array}$} & \multirow{2}{*}{$\begin{array}{c}\text { BCR } \\
\text { 2017-18 }\end{array}$} & \multirow{2}{*}{$\begin{array}{c}\text { BCR } \\
\text { 2018-19 }\end{array}$} & \multirow{2}{*}{$\begin{array}{l}\text { AVERAGE } \\
\text { BCR }\end{array}$} \\
\hline & $\begin{array}{c}(2017- \\
18)\end{array}$ & $\begin{array}{c}(2018- \\
19)\end{array}$ & & & & & & & \\
\hline T1: Happy Seeder & 3780 & 3613 & 47770 & 53400 & 122850 & 126455 & 2.57 & 2.37 & 2.46 \\
\hline $\begin{array}{l}\text { T2: Conventional } \\
\text { sowing }\end{array}$ & 3180 & 3075 & 49975 & 55856 & 103350 & 107625 & 2.07 & 1.93 & 1.99 \\
\hline $\begin{array}{c}\text { T3: Rotavator two } \\
\text { times }\end{array}$ & 3217 & 3125 & 48270 & 54000 & 104552.5 & 109375 & 2.17 & 2.03 & 2.09 \\
\hline $\begin{array}{l}\text { T4: Burning and } \\
\text { conventional } \\
\text { sowing }\end{array}$ & 3049 & 2800 & 49975 & 55856 & 99092.5 & 98000 & 1.98 & 1.75 & 1.86 \\
\hline
\end{tabular}

\section{Conclusion}

It is concluded from the research study that happy seeder sown wheat gave more grain yield as well as proved more economical for sowing of wheat in rice-wheat cropping system. The Happy Seeder provides the capability of sowing wheat in rice stubble with zero tillage, at the same time as increasing yield of crop. The technology escapes the prerequisite for burning of Rice straw and stubbles by protecting the environment from Air Pollution. The technology also fetches many other benefits including preservation of organic matter, destruction of weeds and soil evaporation.

\section{Author's Contribution}

Formal analysis, MAMOONA Shehzadi and ADEEL AHMAD; Investigation, Muhammad Shafqat; Methodology, MUHAMMAD YOUNUS; Software, MUBASHRA YASIN; Supervision, RASHAD UL SHER; Writing - review \& editing, ABDUL KHALIQ. 


\section{REFERENCE}

1. Singh, R.A.; Singh, J.; Yadav, D.; Singh, H.K.; Singh, J. (2012). Integrated nutrient management in ricewheat cropping system. Int. J. Agric. Sci., 8, 523-526.

2. Rahman, M.A., Chikushi J., Saifizzaman M. and Lauren J.G. (2005). Rice straw mulching and nitrogen response of notill wheat following rice in Bangladesh. Field Crops Research 91, 71-81.

3. Sidhua HS, Manpreet S, Yadvinder S, J. Black WS, E. Humphreysd, M.L.Jate VS. Sarbjeet S (2015). Development and evaluation of the Turbo Happy Seeder for sowing wheat into heavy rice residues in NW India. Advances in Health and Environment Safety. 47-55. https://doi.org/10.1016/j.fcr.2015.07.025.

4. Timsina, J.; Connor, D.J. (2001). Productivity and management of rice-wheat cropping systems: Issues and challenges. Field Crop. Research. 69:93-132.

5. Kalhapure, A.; Singh, V.P.; Kumar, R.; Pandey, D.S. (2015). Tillage and nutrient management in wheat with different plant geometries under rice-wheat cropping system: A review. Basic Res. J. Agric. Sci. Rev. 2015, 4, 296-303.

8 Kumari, R.; Kumar, S.; Kumar, R.; Das, A.; Kumari, R.; Choudhary, C.D.; Sharma, R.P (2017). Effect of long-term integrated nutrient management on crop yield, nutrition and soil fertility under rice-wheat system. (2017). J. Appl. Nat. Sci, 9: 1801-1807.

9. Jain, N., Bhatia, A., Pathak, H, (2014). Emission of air pollutants from crop residue burning in India. Aerosol Air Qual. Res. 14: 422-430.

10. Kumar, P., Kumar, S., Joshi, L, (2015). Socioeconomic and Environmental Implications of Agricultural Residue Burning. Springer Briefs in Environmental Science.

11. Singh, R., Srivastava, M., Shukla, A (2016). Environmental sustainability of bioethanol production from rice straw in India: A review. Renew. Sustain. Energy Rev. 54, 202-216.

12. Singh J., Singhal N., Singhal S., Sharma M., Agarwal S., Arora S. (2018). Environmental Implications of Rice and Wheat Stubble Burning in North-Western States of India. In: Siddiqui N., Tauseef S., Bansal K. (eds) Advances in Health and Environment Safety. Springer Transactions in Civil and Environmental Engineering. Springer, Singapore. https://doi.org/10.1007/978-981-10-7122-5 6.

13. Sharma S, Rajeev Pand Upendra K. (2019). Integrated Nutrient Management in Rice-Wheat Cropping System: An Evidence on Sustainability in the Indian Subcontinent through Meta-Analysis. Agronomy, 9(71): 1-15.http://doi:10.3390/agronomy9020071.

14. Steel, R. G. D. and J.H. Torrie. (1997). Principles and procedures of Statistics. 2nd Ed.,Mc. Graw Hill Book Co.,Inc., New York:187-88 